\title{
Nephrotic Range of Proteinuria in Congenital Cyanotic Heart Disease: A Rare Complication
}

\author{
AZMERI SULTANA ${ }^{1}$, NAHARUMAAIVE HYDER CHOWDHURY ${ }^{2}$, JESMIN HOSSAIN², \\ SHAHREEN KABIR ${ }^{3}$, MD. SHAHIDUL ISLAM ${ }^{3}$
}

\begin{abstract}
:
Nephrotic syndrome is a common renal problem in children. But it is an uncommon complication for cyanotic heart diseases. It has been rarely reported in pediatric population with congenital cyanotic heart disease in Bangladesh. We found two cases of congenital cyanotic heart disease those were referred to investigate for nephrotic range of proteinuria.
\end{abstract}

Keywords: Nephrotic range proteinuria, congenital cyanotic heart disease (CHD).

\section{Introduction}

Congenital cyanotic heart disease (CHD) can be presented with protein leak resulting from glomerular injury especially in older children and adults. Nephrotic range of proteinuria is a serious complication of cyanotic congenital heart disease. ${ }^{1,2}$ Histopathologic findings in patients with congenital heart disease found to have glomerular enlargement, capillary dilatation, capillary thickening, focal or diffuse mesangial proliferation, and segmental or global glomerulosclerosis. ${ }^{3}$ Although proteinuria is the major urinary abnormality in patients with congenital cyanotic heart disease, nephrotic syndrome is an uncommon complication and renal biopsy has been seldom performed. ${ }^{4}$ The risk of developing renal impairment is high in cyanotic patients particularly in patients with long-standing cyanotic congenital heart disease. ${ }^{1}$

Case 1: A 10-year-old girl diagnosed as a case of congenital cyanotic heart disease (Pulmonary stenosis) referred to us from the National Heart Foundation for the evaluation of proteinuria. She was admitted to that hospital with the complaints of bluish discoloration of lips, fingers, and toes and

1. Associate professor of pediatric nephrology, Dr M R Khan Shishu (Children)Hospital and Institute of Child health.

2. Assistant professor of pediatric cardiology, National heart foundation Hospital and research Institute.

3. Registrar, pediatric cardiology, National heart foundation Hospital and research Institute.

Correspondence: Azmeri Sultana, Associate professor of pediatric nephrology, Dr M R Khan Shishu (Children)Hospital and Institute of Child Health, Cell no- 01972817777, email: jhilni_me@yahoo.com

Received: 16/08/2020 breathlessness on effort. The girl had a puffy face, cyanosis (SPO2 50\%), and clubbing. Her blood pressure was 100/60 $\mathrm{mm}$ of $\mathrm{Hg}$, jugular venous pressure was not raised. Precordium examination revealed apex beat located on left 4 th ICS, $1^{\text {st }}$ and $2^{\text {nd }}$ heart sound was audible in all four areas with systolic murmur (grade 3/6) best heard over the left $4^{\text {th }}$ area without any radiation. Other systems revealed nothing abnormalities. Her urine R/M/E revealed albumin++, pus cell 0-2/ HPF, No R.B.C in urine. Urinary spot protein creatinine ratio $0.4 \mathrm{gm} / \mathrm{mmol}$ (nephrotic range), Serum Albumin $2.8 \mathrm{gm} / \mathrm{dl}$ and Serum cholesterol 120 $\mathrm{mg} / \mathrm{dl}$. Her Echo report revealed situs solitus, levocardia, severe valvular pulmonary stenosis (PPG=102mm of $\mathrm{Hg}$ ), severe TR, PFO. Hypertrophied RV with moderate RV systolic dysfunction. Cardiac catheterization showed severe valvular pulmonary stenosis with coarse trabeculated hypertrophied RV. As there was no hematuria or high BP and also the patient's condition was not so good so we didn't performed a renal biopsy and started Enalapril along with her cardiac treatment. We also plan for treatment with steroids after doing a biopsy. But within 2 days of admission, her condition deteriorated and she died on $18 / 04 / 2019$. The cause of death was multi-organ failure due to severe pulmonary stenosis and severe RV dysfunction. Unfortunately, we lost the child.

\section{Case 2:}

An 8-year-old boy with edema, dyspnea, and cyanosis was admitted to our hospital in December 2018. He was first diagnosed as a case of TOF at the age of 18 months when presented with cyanosis and respiratory difficulty. At that time Blalock-Taussig (BT) shunt 
shunt was performed (2011). After that, they lost to follow up with the pediatric cardiologist. His recent physical examination revealed respiratory distress with edema and episodes of squatting. He was cyanosed and found to have clubbing on fingers and toes. The apex beat was at the fifth intercostal space along the anterior axillary line. Both first heart sound (S1) and second heart sound (S2) were noted with a systolic thrill and loud systolic ejection murmur grade $3 / 6$. The blood pressure was $110 / 70 \mathrm{mmHg}$, and oximetry showed SPO2 63\%. A complete blood count showed hemoglobin $18.2 \mathrm{~g} / \mathrm{dL}$, total proteins $45 \mathrm{~g} / \mathrm{L}$, and albumin $22 \mathrm{~g} / \mathrm{L}$. Dipstick urinalysis was $3+$ while urine protein creatinine ratio $0.6 \mathrm{gm} / \mathrm{mmol}$. Creatinine was $37 \mathrm{mmol} / \mathrm{L}$, urea was $3.8 \mathrm{mmol} / \mathrm{L}$, and cholesterol was $4.2 \mathrm{mmol} / \mathrm{L}$. X-ray chest revealed a typical "bootshaped" heart with an upturned cardiac apex. Echocardiography revealed the tetralogy of Fallot with hypoplastic pulmonary artery and biventricular dysfunction. Cardiac catheterization was not performed due to technical reasons. A diagnosis of Fallot's tetralogy and Nephrotic range of proteinuria was established. Renal biopsy was not performed due to the critical condition of the patient. During his hospitalization, the child received treatment Propranolol ( $2 \mathrm{mg} / \mathrm{kg} / \mathrm{day}$, four divided dose), and Enalapril ( $0.4 \mathrm{mg} / \mathrm{Kg} /$ day, every twelve hours). Initial biologic and clinical improvement was observed with Enalapril therapies. Edema regressed with treatment. The 24-hour urinary protein decreased from $0.6 \mathrm{gm} /$ $\mathrm{mmol}$ to $0.3 \mathrm{gm} / \mathrm{mmol}$ and creatinine remained stable. The patient discharged and he underwent total corrective surgery on 2019 May. We follow up patient for proteinuria but he is protein-free since august 2019 and we stopped Enalapril in September 2019. His last follow up was in December 2019. He was acyanotic, His BP was $90 / 60 \mathrm{~mm}$ of $\mathrm{Hg}$, His blood report showed $\mathrm{Hb} 13.5 \mathrm{gm} / \mathrm{dl}$, S creatinine $0.4 \mathrm{mg} / \mathrm{dl}$, urine routine examination showed albumin nil, no pus cell or R.B.C. Urinary spot protein creatinine ratio $0.01 \mathrm{gm} / \mathrm{mmol}$.

\section{Discussion:}

The development of proteinuria associated with cyanotic $\mathrm{CHD}$ though remains unclear, a large number of reports have described potential mechanisms. Patients with cyanotic CHD are exposed to chronic hypoxia which leads to glomerular injury. The risk of developing glomerular lesions rose sharply during the second decade of life if the cyanosis remains unchanged for more than ten years Polycythemia causes hyperviscosity which induces an angiogenic increase in the glomerular capillary beds, in turn leading to glomerulomegaly. Glomerulomegaly is a consequence of the hyperperfusion of glomeruli associated with chronic hypoxia and the increased hydrostatic pressure in the capillary wall. This situation act as a causative factor for the deterioration and the decline of renal function, in the condition of polycythemia. Furthermore, the failure of a compensatory mechanism to respond to reduced renal blood flow by hyperfiltration may be accompanied by the development and progression of microalbuminuria and proteinuria. ${ }^{7,8}$ Hypoxia, raised hematocrit, and polycythemia may be contributory factors for glomerulopathy in congenital cyanotic heart disease, but it is not always necessary conditions. Some studies linked cardiac defect with steroid-resistant nephrotic syndrome by mutation of NPHS2 gene encoding podocin. ${ }^{9-11}$

The literature review showed involvement of kidneys in congenital cyanotic heart disease is late. But Pépé Mfutu Ekulu et al reported one case of Tetralogy of Fallot presented with nephrotic syndrome at 4 years. ${ }^{12}$ Our two cases presented a little late, one patient at 10 years and another at 8 years which is similar to a case report from Nigeria. ${ }^{13}$ Our first case presented late. This case revealed the problem of early diagnosis, regular follow-up, and early detection of complications. It is already known that untreated cardiac malformations inpatient with Fallot's tetralogy or cyanotic congenital heart disease have a high likelihood of progression to glomerular damage. . $^{4-6}$

In the second case, we started ACE inhibitor (Enalapril) which seemed to be effective for reducing proteinuria may be glomerular hyperfiltration was probably the most important causative factor for proteinuria. In a retrospective analysis between 1973 and 1989, Flanagan et al. ${ }^{14}$ did not report any nephrotic syndrome cases in 83 congenital cyanotic heart disease patients, with or without urinary abnormalities, which were treated with ACEI (captopril). Another two studies reported remission of nephrotic syndrome with ACE inhibitor in a patient who has cyanotic heart disease with focal segmental glomerulosclerosis (FSGS). ${ }^{15,16}$

Our second case responded well with ACE inhibitor and lastly, we stopped this medicine as there was no proteinuria. Improved hypoxia and polycythemia after surgical correction may results in good renal perfusion. 
Another two studies reported renal biopsy findings in congenital cyanotic heart disease with proteinuria showed light microscopic findings were glomerulomegaly, with 12 glomeruli 3 had global sclerosis and 3 had focal segmental glomerular sclerosis. Electron microscopy showed segmental hyalinosis of glomeruli and some podocyte hypertrophy. Immunofluorescence imaging revealed focal segmental deposition of IgM and C3 in mesangium. ${ }^{15,16}$ We did not perform renal biopsy as first case was in critical condition and later on expired, and second case responded well with enalapril.

\section{Conclusion:}

Children with congenital cyanotic heart disease can be presented with a nephrotic range of proteinuria. Some may present with Focal segmental glomerulosclerosis (FSGS). ACE inhibitor seems to be effective for reducing proteinuria. All congenital cyanotic heart disease patients who are not going for surgery and chance of long-standing hypoxia may need renal follow up for early detection of renal involvement.

\section{References:}

1. Ogunkunle O, Asinobi A, Omokhodion S, Ademola A. Nephrotic syndrome complicating cyanotic congenital heart disease: a report of two cases. West African Journal of Medicine. 2008; 27: 263-66.

2. Caridi G, Bertelli R, Carrea A, Duca MD, Catarsi P, Artero M et al. Prevalence, genetics, and clinical features of patients carrying podocin mutations in steroid-resistant nonfamilial focal segmental glomerulosclerosis. J Am Soc Nephrol. 2001; 12: 2742-46.

3. Spear GS. The glomerulus in cyanotic congenital heart disease and primary pulmonary hypertension. Nephron. 1964; $1: 238-48$

4. Hagley MT, Murphy DP, Mullins D, Zarconi J. Decline in creatinine clearance in a patient with glomerulomegaly associated with a congenital heart disease. Am J Kid Di.1992;20:177-78.
5. Cochat $\mathrm{P}$, Mourani $\mathrm{C}$, Exantus J, Martinaze $\mathrm{P}$, Adonis $\mathrm{K} \mathrm{L}$, Bacchetta J. Pediatric nephrology in developing countries. Medicine Tropicale. 2009; 69: 543-47.

6. Dittrich S,Haas NA, Bührer C, Müller C, Dähnert I,Lange $P E$. Renal impairment in patients with long-standing cyanotic congenital heart disease. Acta Paediatrica.1998; 87: 949-54.

7. Krull F, Ehrich JHH, Wurster U, Toel U, Rothgänger S, and Luhmer I. Luhmer, Renal involvement in patients with congenital cyanotic heart disease. Acta Paediatrica Scandinavica.1991;80: 1214-19.

8. Inatomi J, Matsuoka K, Fujimaru R, A. Nakagawa A, lijima $\mathrm{K}$. Mechanisms of development and progression of cyanotic nephropathy. Pediatric Nephrology. 2006; 21: 1440-45.

9. Yaacov F, Sofia F, Choni R, Rachel B Cohen, Israela L, Annick Raas-Rothschild. The Heart of Children with Steroid-Resistant Nephrotic Syndrome: Is It All Podocin. JASN 2006; 17: 227-31.

10. Gianluca Caridi, Monica Dagnino, Alba Carrea, Laura Massella, Alessandro Amore, Francesco Emma. Nephrology Dialysis Transplantation.2007; 22:1477-79.

11. Rosenthal G. Prevalence of congenital heart disease. In: The Science and Practice of Pediatric Cardiology $2^{\text {nd }}$ ed. Baltimore. Garson A, Bricker JT, Fisher DJ, Neish SR, Williams \& Wilkins publisher;1998. pp1089-93

12. Pépé Mfutu E, Kazadi-wa-Kazadi O, Paul KL, Michel NA. Nephrotic syndrome in a child suffering from Tetralogy of Fallot. Case Reports in Pediatrics.2015; 15:1123-25.

13. Dittrich S, Haas NA, Bührer C, Müller C, Dähnert I, Lange $P E$. Renal impairment in patients with long-standing cyanotic congenital heart disease. Acta Paediatrica.2017; 87: 949-54.

14. Flanagan MF, Hourihan M, Keane JF. Incidence of renal dysfunction in adults with cyanotic congenital heart disease. Am J Cardiol.1991;68: 403-06

15. Kazuyuki H, Jun W, Hiroko Y, Yoshio N, Hong Z, Hitoshi S. Cyanotic congenital heart disease associated with glomerulomegaly and focal segmental glomerulosclerosis: remission of nephrotic syndrome with angiotensin converting enzyme inhibitor. Nephrology Dialysis Transplantation.2002;17:144-47.

16. Fujimoto Y, Matsushima M. Tsuzuki K, Okada M,Shibata M, Yanase $\mathrm{Y}$, et al. Nephropathy of cyanotic congenital heart disease: clinical characteristics and effectiveness of an angiotensin-converting enzyme inhibitor. Clinical Nephrology.2002; 58: 95-102. 